\title{
WHY LEGAL WRITING IS "DOCTRINAL" AND MORE IMPORTANTLY PROFOUND
}

\author{
Harold Anthony Lloyd*
}

\section{A Challenge to the Way We SPEAK of Legal Writing}

I want to challenge everyone (including law professors who teach legal writing) to stop directly and indirectly referring to legal writing as a "nondoctrinal" course. I want to challenge everyone (including law professors who teach legal writing) to avoid saying such things as, "How does the time required for students' doctrinal course assignments compare with the time required for students' legal writing assignments?" As long as we must use the word "doctrinal," I hope we would rephrase such questions as follows: "How does the time required for students' other doctrinal course assignments compare with the time required for students' legal writing assignments?" Ultimately, I hope we will dispose of the term "doctrinal" and instead speak of "meaningful" courses and their "intertwined proper theory and proper practice."

Why do I quibble about such syllables? I quibble because "non-doctrinal" in the law school context can be code for "lesser," and can suggest that legal writing has lesser import than other law school courses. ${ }^{2}$ To the extent such code $^{3}$ marks legal writing as "lesser," it damages legal education across the board. It damages students and law professors not teaching legal writing by

\footnotetext{
* (C)2018 Harold Anthony Lloyd. I would like to thank Elon Law School for letting me speak about this topic on December 8, 2017, and I would also like to thank Professor Sue Liemer and others for encouraging me to put to paper some of what I said on that day. I am also grateful to Professor Laura Graham and Professor Christine Coughlin for their thoughts and comments. Any errors or other shortcomings are my own.

1 By "meaningful," I mean a course that recognizes and effectively employs the fusion of theory and practice that both reality and semantics require. See Harold Anthony Lloyd, Theory Without Practice Is Empty; Practice Without Theory Is Blind: The Inherent Inseparability of Doctrine and Skills, in Linda H. EdWARdS, The Doctrine-SKILls Divide: LeGAL EduCATION's SELF-INFLICTED Wound 77-90 (2017) [hereinafter Lloyd, Theory Without Practice]. By "intertwined proper theory and proper practice," I would further recognize such required fusion of theory and practice. See id.

2 See Linda H. Edwards, Legal Writing: A Doctrinal Course, 1 Savannah L. Rev. 1, 9-12 (2014). This excellent article is essential reading for anyone interested in the "doctrinal" status of legal writing.

${ }^{3}$ I concede at the outset that worse code words exist than "non-doctrinal." For example, parsing "substantive" and "non-substantive" courses suggests "non-substantive" courses lack substance. Id. at 2. However, I agree with Professor Edwards that talk of legal writing as "non-substantive" seems on the wane because of the suggestion of "little substance," and I shall not pursue that term further here. See id. at 2.
} 
suggesting that legal writing, and the theory, skills, and insights taught by legal writing, merit less of their time. ${ }^{4}$ This, in turn, increases the odds that both students and other faculty will remain ignorant of the critical knowledge and skills that legal writing teaches. It also damages law professors teaching legal writing because it invites disparate treatment such as lack of tenure, lower pay, and lack of equal respect. ${ }^{5}$ As a result, law professors teaching legal writing also have more difficulty in publishing scholarship, ${ }^{6}$ a difficulty which deprives us all of the scholarship so silenced or deterred. ${ }^{7}$

\section{LAW SCHOOL COURSES AND “DOCTRINAL" IN NON-CODED, ORDINARY LANGUAGE}

If we are to use "doctrinal" to parse among courses, let us, therefore, put aside such damaging code usage and inquire what "doctrinal" actually means in its standard or dictionary senses. According to The American Heritage Dictionary, "doctrinal" means "[c]haracterized by, belonging to, or concerning doctrine." 8 This definition thus incorporates "doctrine," which has the following meanings with the "central and often the most commonly sought meaning" listed first: ${ }^{9}$

1. A principle or body of principles presented for acceptance or belief, as by a religious, political, scientific, or philosophic group; dogma.

2. A rule or principle of law, especially when established by precedent.

3. A statement of official government policy, especially in foreign affairs and military strategy.

4. Archaic Something taught; a teaching. ${ }^{10}$

The Merriam-Webster's Collegiate Dictionary differs a bit here by including "something that is taught"11 under the non-archaic definition of "doctrine," though that sense is the oldest of the non-archaic senses. ${ }^{12}$

4 See id. at 9-10.

5 See Harold Anthony Lloyd, Exercising Common Sense, Exorcising Langdell: The Inseparability of Legal Theory, Practice, and the Humanities, 49 WAKE ForEST L. REV. 1213, 1245 (2014) [hereinafter Lloyd, Exercising Common Sense].

6 See Edwards, supra note 2, at 10.

7 The legality of such disparate treatment is beyond the scope of this paper. I would note, however, that legal writing has often been seen as "a woman's job." Ann C. McGinley, Reproducing Gender on Law School Faculties, in EDWARDS, supra note 1, at 240 (internal quotation marks omitted). The reader can take it from there.

8 Doctrinal, The American Heritage Dictionary (5th ed. 2016).

9 The American Heritage Dictionary xxiv (5th ed. 2016) ("Entries containing more than one sense are arranged ... with the central and often the most commonly sought meaning first.").

10 Doctrine, The American Heritage Dictionary (5th ed. 2016).

11 Doctrine, Merriam-Webster's Collegiate Dictionary (11th ed. 2014).

12 See Merriam-Webster's Collegiate Dictionary 20a (11th ed. 2014) ("The order of senses within an entry is historical: the sense known to have been first used in English is entered first.”). 
Taking these four definitions in turn, we can see that only two are plausible fits for even torts, contracts, and other law school courses that would traditionally claim to be "doctrinal."

\section{A. "Doctrine" in the First Sense}

The first and thus "central and often the most commonly sought" sense of "doctrine" ("[a] principle or body of principles presented for acceptance or belief, as by a religious, political, scientific, or philosophic group; dogma"13) seems at best an imperfect fit because of the "dogma" language. ${ }^{14}$ Litigators do, of course, "present" arguments to courts that certain principles or rules should be accepted or followed. We also debate rules or principles in class. However, no lawyers or legal scholars should ever dogmatically "believe in" everything that purports to be law. No one, for example, should have ever "believed in" the principle or rule of separate but equal set forth in Plessy v. Ferguson. ${ }^{15}$ Lawyers and scholars should instead call out injustice and bad precedent rather than simply "believe" in it. Additionally, to the extent the first definition might also construe law as some Langdellian "science" of certain rules, ${ }^{16}$ I have addressed that sort of silliness elsewhere ${ }^{17}$ and will not repeat my arguments here.

We might attempt to avoid these "dogma" problems by going off script and truncating the definition to eliminate the reference to "dogma" and thereby focus more on "a principle or . . body of principles." ${ }^{18}$ However, I believe this

13 Doctrine, The American Heritage Dictionary, supra note 10.

14 "Dogma" means "1. A doctrine or a corpus of doctrines relating to matters such as morality and faith, set forth in an authoritative manner by a religion. 2. A principle or statement of ideas, or a group of such principles or statements, especially when considered to be authoritative, or accepted uncritically.” Dogma, The American Heritage Dictionary (5th ed. 2016). Such uncritical acceptance seems a fatal taint to me when applying this definition to the law.

15 See generally Plessy v. Ferguson, 163 U.S. 537 (1896).

16 As I have written before, Christopher Columbus Langdell did much damage to legal education with his "wrong and counterintuitive notions ... [that] law is a science of principles and doctrines known with certainty and primarily traced through case law." Harold Anthony Lloyd, Raising the Bar, Razing Langdell, 51 WAKE FOREST L. REV. 231, 231 (2016) [hereinafter Lloyd, Raising the Bar].

17 See generally id. at 231-36.

18 Professor Edwards takes this approach. See Edwards, supra note 2, at 3. She uses Merriam-Webster's online definition of "doctrine" which as of February 21, 2019 reads in full as follows:

1 archaic: teaching, instruction

$2 \mathrm{a}$ : something that is taught

$\mathrm{b}$ : a principle or position or the body of principles in a branch of knowledge or system of belief :

dogma

// Catholic doctrine

c law : a principle of law established through past decisions

$\mathrm{d}$ : a statement of fundamental government policy especially in international relations

// the Truman Doctrine

e : a military principle or set of strategies 
would risk altering the first meaning by removing the textual context provided by the word "dogma." 19 Before risking this, we should explore whether other terms and phrases-such as "meaningful" and "intertwined proper theory and proper practice" 20 - discussed in this article prove more useful.

\section{B. "Doctrine" in the Second Sense}

The second presumably most "central" or "commonly sought" sense of "doctrine" ("[a] rule or principle of law, especially when established by precedent"21) employs the term "law" and thus can, no doubt, be of at least some use. However, the qualifier of "especially when established by precedent" raises issues. Is the Uniform Commercial Code, for example, "law" and thus "doctrinal" to the extent it has not been established by a judicial ruling? And what about statutes? How does the qualifier apply to them? Though I will try to work with this second sense in Part III below, we can already see that it is not a perfect fit even with other courses (such as Uniform Commercial Code or statutory courses) that would elevate themselves with the term "doctrinal." 22

\section{C. "Doctrine" in the Third Sense}

The third presumably most "central" or "commonly sought" sense of "doctrine" ("[a] statement of official government policy, especially in foreign affairs and military strategy" ${ }^{23}$ ) seems of little use here, and I shall not pursue it further.

\section{D. "Doctrine" in the Fourth Sense}

This leaves us with the possibly archaic sense of "doctrine" as "[s]omething taught; a teaching." 24 In addition to the potential problems of using words in senses no longer used in ordinary language, this definition has an overbreadth problem. Since such things as alchemy, witchcraft, and even utter

Doctrine, MERRIAM-WeBSTER.COM, https://www.merriam-webster.com/dictionary/doctrine [https://perma.cc/L6JB-J8AB] (last visited Feb. 21, 2019). Professor Edwards examines "a principle or position or the body of principles in a branch of knowledge or system of belief" without reference to "dogma." See Edwards, supra note 2, at 3.

19 See Harold Anthony Lloyd, Law's "Way of Words": Pragmatics and Textualist Error, 49 CREIGHTON L. ReV. 221, 259-60 (2016) (discussing textual context).

20 See, e.g., Lloyd, Theory Without Practice, supra note 1; see also discussion infra Sections II.E, IV.

21 Doctrine, The American Heritage Dictionary, supra note 10.

22 The Uniform Commercial Code is a model code under the charge of the Uniform Law Commission and the American Law Institute. See 2017-2018 Rules OF ConTraCt LAw 36163 (Charles L. Knapp et al. eds., 2017). Statutes are, of course, products of the legislative and not judicial branches of government. See, e.g., Christine COUGHLIn ET AL., A LAWYER WRITES 16 (2d ed. 2013).

23 Doctrine, The American Heritage Dictionary, supra note 10.

24 See id. 
nonsense, for example, can be taught, such things would also fall under the title of "doctrinal."

At this point, we should have serious questions about how a "doctrinal" label could elevate any "meaningful" law school course over another. We should also have serious questions about whether "doctrinal" has any desirable law school usage given the limitations of senses one through three, the extreme breadth and possibly archaic nature of sense four, and the damaging code connotations of the term when used in the law school context.

\section{E. "Doctrine" Versus "Intertwined Proper Theory and Proper Practice"}

Before going further, I should note that not all people who object to the use of "doctrinal" to lessen the status of legal writing would agree with the scope of my doubts about the term "doctrinal." For example, while Professor Linda Edwards and I agree that we should not use "doctrinal" to "distinguish legal writing from other courses" and that "we should use the term often and intentionally to describe Legal Writing." 25 I, for the reasons set forth in this article, would use the term only so long as others continue to insist on its usage. In contrast, Professor Edwards believes that "doctrine" has important curricular usage because "[d]octrine defines a discipline's scholarship and therefore what counts as disciplinary knowledge and what does not." 26

Given the limitations of senses one through three of "doctrine," the extreme breadth and possibly archaic nature of the fourth sense of the term, and the damaging code connotations of the term in the law school context, I would rather use a phrase involving the applicable intertwined proper theory and proper practice when asking what defines "scholarship" for a given course. Asking what is the proper intertwined theory and practice for contracts and legal writing, for example, helps define course content and scholarship without the accompanying baggage that "doctrine" brings along. Inquiring as to proper intertwined theory and practice on its face considers the continuing relevance of current norms for a current subject matter. ${ }^{27}$ However, by asking what is "proper," such a question also recognizes not only that given concepts can be debated but that concepts can also be framed and fleshed out in different ways

25 Edwards, supra note 2, at 2, 17.

26 Id. at 10.

${ }^{27}$ I agree with Professor Edwards that subject matters can involve norms that one must accept or challenge and that "commonly accepted" notions are "privileged" in the sense that ideas already accepted in a given subject matter are more welcomed than those that are not. See id. at 11. I disagree, however, that we need the term "doctrine" to account for this "heavy thumb on the scales of knowledge development." See id.; see also ROBERT BENSON, The InTerpretation Game: How Judges and Lawyers MaKe the Law 74, 79 (2008) ("[I]nterpretive communities" have constraints that are "subject to change" though "extremely hard to budge" and "social meanings" are "the meanings other interpreters are persuaded to share.") (quotation marks omitted). 
that we can then put to the test of experience and debate. ${ }^{28}$ "A principle or body of principles presented for acceptance or belief . . ; dogma" (the first sense of "doctrine" ${ }^{29}$ ) seems less inviting: are we to take all such "doctrine" like dogma and accept it "uncritically?"30

\section{F. "Doctrinal” and Wittgenstein's Ladder}

If it were up to me alone, I would simply dispose of the term "doctrinal." Since, however, it is not up to me alone, I will, therefore, use the term "doctrinal" here in much the same spirit that Wittgenstein used his Tractatus: as a ladder to be tossed away once we have climbed it to clearer heights. ${ }^{31}$ In such a Wittgensteinian spirit, I shall therefore explore whether legal writing is "doctrinal" in the second and fourth senses of "doctrine" noted above (with the other senses again being of questionable or little use ${ }^{32}$ ).

\section{LEGAL WRITING AND THE “DOCTRINAL" IN NON-CODED, ORDINARY LANGUAGE}

\section{A. "Doctrine" in the Second Sense}

Taking first, therefore, the second presumably most "central" or "commonly sought" meaning of "doctrine" ("[a] rule or principle of law, especially when established by precedent" ${ }^{\prime 3}$ ), legal writing more than holds its own with other "doctrinal" courses. At Wake Forest, for example, we have an intensive Foundations Week before other courses start where legal writing is the first course to teach (among other things): (i) basics of stare decisis, (ii) the fundamental parts and basic types of judicial opinions (majority, plurality, dissent), (iii) basics of that troublemaker dictum, (iv) sources and hierarchies of the law (including judicial decisions), (v) the distinction between the rule of a case and the holding of a case, (vi) synthesizing judicial rules, (vii) distinguishing between elements and factors in judicial decisions, (viii) jurisdiction basics, and (ix) how to brief a case. ${ }^{34}$ As legal writing continues at Wake Forest, legal writing, among other things: (x) continues to flesh out the above, (xi) explores case illustrations and

28 See Harold Anthony Lloyd, Good Legal Thought: What Wordsworth Can Teach Langdell About Forms, Frames, Choices, and Aims, 41 VT. L. REV. 1, 7-12 (2016) [hereinafter Lloyd, Wordsworth] (on framing); Harold Anthony Lloyd, Law as Trope: Framing and Evaluating Conceptual Metaphors, 37 PACE L. REV. 89, 102-07 (2016) (on experience and workability).

29 Doctrine, The American Heritage Dictionary, supra note 10.

30 Dogma, The American Heritage Dictionary, supra note 14.

31 See Ludwig Wittgenstein, Tractatus Logico-Philosophicus 74 (D.F. Pears \& B.F. McGuinness, trans., Routledge \& Kegan Paul 1978) (One must "throw away the ladder after he has climbed up it," and one "must transcend these propositions, and then he will see the world aright.").

32 See supra Sections II.A, II.C.

33 Doctrine, The American Heritage Dictionary, supra note 10.

34 Syllabi on file with author; see also CoUGHLIN ET AL., supra note 22, at 15-73. 
their parts, (xii) teaches canons of construction, and (xiii) examines and applies analogical reasoning and counter-analyses in common law contexts. ${ }^{35}$ Legal writing is thus undoubtedly "doctrinal" in the sense of teaching legal rules or principles, especially those formed by precedent.

\section{B. "Doctrine" in the Fourth Sense}

Taking next the fourth, and possibly archaic, meaning of "doctrine" as "something taught," ${ }^{36}$ no reasonable person would maintain that legal writing is not "something taught." Rather than defend the obvious here, I shall instead survey more of legal writing's "something taught."

In addition to the crucial matters discussed above, legal writing also explores the interpretation, construction, and application of statutes. ${ }^{37}$ This adds critical depth to legal curriculums caught up in Langdell's obsession with redacted appellate cases. ${ }^{38}$ Additionally, legal writing teaches basic forms of good thought (IRAC, CREAC, and RIRAC, for example ${ }^{39}$ ) as well as when and how to vary them. ${ }^{40}$ What can be more central to legal scholarship than that? Legal writing teaches both objective and persuasive thought and writing. ${ }^{41}$ What can be more central to legal scholarship than that? Legal writing teaches students how to find, understand, and apply law and arguments. ${ }^{42}$ What can be more central to legal scholarship than that? Legal writing also teaches rules of civil and appellate procedure - especially as it moves into persuasive writing. ${ }^{43}$ What can be more central to legal scholarship than that?

Though it might seem impossible for a single course to teach even more, legal writing indeed teaches more-much more. Legal writing teaches rhetoric in the classical sense. It teaches at least two of the three branches of rhetoric: the deliberative (objective and persuasive writing as to future action) and the judicial (objective and persuasive writing as to past action). ${ }^{44}$ Legal writing also teaches at least four of the five parts of classical rhetoric: Invention, Arrange-

35 Syllabi on file with author; see also COUGHLIN ET AL., supra note 22, at 15-162.

36 Doctrine, The American Heritage Dictionary, supra note 10.

37 Syllabi on file with author; see also COUGHLIN ET AL., supra note 22, at 38-43, 181-97.

38 See generally Lloyd, Raising the Bar, supra note 16, at 231-37.

39 Syllabi on file with author; see also COUGHLIN ET AL., supra note 22, at 81-85. For "RIRAC," see generally Lloyd, Wordsworth, supra note 28, at 13-15.

40 See Lloyd, Wordsworth, supra note 28, at 15-16.

41 See generally Coughlin ET AL., supra note 22; JoAn M. Rocklin ET AL., An Advocate PeRsuAdes (2016).

42 See Coughlin ET AL., supra note 22, at 57-66, 129-65.

43 See generally RocKLIN ET AL., supra note 41, at 49-59, 75-98.

44 See generally Coughlin ET AL., supra note 22, at 3 (as to objective writing); RICHARD A. Lanham, A Handlist of Rhetorical Terms 164 (2d ed. 1991) (setting out the three branches of Rhetoric); ROCKLIN ET AL., supra note 41, at 3 (as to persuasive writing). 
ment, Style, and Delivery. ${ }^{45}$ Legal writing, additionally, explores the two types of proof: the deductive and inductive. ${ }^{46}$ In my first-year legal writing course, I also like to combine the two types of proof with an overview of fallacious reasoning. What other law school course does all of this? "Doctrinal" legal writing as "something taught" thus holds its own against any other "doctrinal" course we commonly see in law school today.

Were all this coverage and depth not amazing enough, legal writing can boast of even more. To the misguided contracts professor ${ }^{47}$ who, for example, considers legal writing "non-doctrinal" or "something lesser," I would point out the following contract assignments in my first-year objective legal writing class. I typically assign as my first "major" assignment an actual commercial lease for the students to read and have them determine whether it contains an implied covenant of continuous operations. The students' work here is deeper than any implied covenant exam question I could imagine in a Commercial Leasing or Contracts class. I also teach Commercial Leasing and do not give exams because of my belief in their often superficial nature. Instead, I require students to demonstrate knowledge and skill through the drafting of lease and lease-related documents. For the second "major" assignment, I typically assign a note and deed of trust for students to read. I then have them write an objective memo on whether the trustee will prevail at her foreclosure hearing and whether injunctive relief is available to the debtor in a separate hearing under the particular facts I give my students to parse. Once more, I find it hard to imagine an exam question in other "doctrinal" courses (such as Remedies or DebtorCreditor Law) which could explore such questions in such depth. For my third "major" assignment, I typically require an objective memo on whether a restrictive covenant is valid in a complex amended employment agreement which the students must also read. This also requires delving into the real world of statutes and unredacted appellate cases that transcend what is simply given in any textbook of redacted cases. Again, it is unlikely that an exam question in another "doctrinal" course (such as Remedies or Employment Law, for example) could match the intellectual rigor this exercise requires. I have no doubt that others who teach legal writing can speak of similar or even more rigorous ex-

45 See generally COUGHLIN ET AL., supra note 22 (as to objective writing); LANHAM, supra note 44, at 165 (setting out the five parts of rhetoric); see also ROCKLIN ET AL., supra note 41 (as to persuasive writing). I also try to talk to students about the fifth part: Memory.

46 See generally LANHAM, supra note 44, at 166 (describing induction and deduction as the two types of "logical proof"); see also ROCKLIN ET AL., supra note 41, at 7-9 (as to "logos").

47 I select a misguided contracts professor here because Langdell's first case book was on

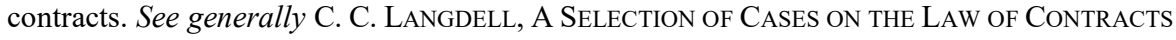
(1871). Far from disliking contracts professors, I long for the day when first year contracts professors will bravely abandon obsessions with redacted appellate cases and teach instead from real contracts, hornbooks, restatements, model codes, hypotheticals, and simulations in ways that add more depth and intellectual rigor to the classroom. See Lloyd, Exercising Common Sense, supra note 5, at 1236-37. 
amples of how their legal writing problems surpass the requirements of exams. $^{48}$

\section{The Further PROFUndity OF LEGAL Writing APART FROM LABELS AND CODED LANGUAGE}

Of course, the high status of legal writing does not depend upon how dictionaries define the word "doctrinal." In addition to the profound scope of legal writing discussed above, basic principles of semantics and modern cognitive psychology further underscore the profundity of legal writing. ${ }^{49}$

Regardless of how one defines "doctrinal," one understands concepts more deeply when one understands how concepts play out in the world of experience. ${ }^{50}$ As I have written on this in detail elsewhere, ${ }^{51}$ I shall merely reiterate here some examples from above. One would no doubt better understand a commercial lease and any implied covenants of continuous operations when one understands how they play out in actual experience. One would no doubt better understand deeds of trust when one understands how they play out in actual experience. One would no doubt better understand restrictive covenants in employment contracts when one understands how they play out in experience. Turning to public law examples, I, no doubt, better understand a statute the more I understand how it plays out in experience. If someone asks me what a statute means, I will flesh it out (note this bodily reference) by describing how it plays out in experience. Such "fleshing out" is at the heart of the skills taught in legal writing where students must produce actual objective and persuasive written and oral products required of practicing lawyers. ${ }^{52}$ Such "fleshing out" is also at the heart of meaning. Though I will not debate various theories of meaning here, ${ }^{53}$ the above examples of "fleshing out" meaning demonstrate that any plausible theory of meaning must involve how notions play out in experience. ${ }^{54}$ In any reasonable semantics, legal writing must, therefore, be a profoundly meaningful course.

Focusing on "fleshing out" also accords with insights of modern cognitive psychology that legal writing also embodies. ${ }^{55}$ These insights recognize that we do not take a purely objective or canonical approach when exploring how con-

48 See, e.g., Edwards, supra note 2, at 5.

49 See Lloyd, Theory Without Practice, supra note 1, at 79-85 (exploring workable theories of meaning and modern cognitive research on embodied meaning theory).

50 Id. at $79,83$.

51 See generally id.

52 See id. at 79-80.

53 See, e.g., Lloyd, Exercising Common Sense, supra note 5, at 1216-18, 1250-54 (exploring various theories of meaning).

54 See generally Lloyd, Theory Without Practice, supra note 1.

$55 \mathrm{Id}$. at 80. 
cepts play out in experience ${ }^{56}$ Instead, we do it from the "perspective of someone actually experiencing the scene." ${ }^{57}$ In other words, meaning is embodied; as George Lakoff puts it, language can only become meaningful through our "sensory-motor and emotional systems, which define goals and imagine, recognize, and carry out actions." 58 Thus, studies have shown that bowlers performed better when they had practiced by visualizing proper bowling techniques, while visualizing bad techniques had reverse results. ${ }^{59}$ And, of course, the absence of visualizing techniques is by definition (to me at least) just empty.

In accordance with such principles of modern cognitive psychology, legal writing both visualizes concepts (such as the issues, rules, ways of applying the rules, and resulting conclusion) ${ }^{60}$ and puts such visualizations into actual practice through the writings and other exercises required in legal writing. ${ }^{61}$ This is best intellectual practices in full accord with the principles of modern cognitive psychology discussed above. Rather than diminishing legal writing, this elevates legal writing's status for those who actually understand how the mind and meaning work.

\section{CONCLUSION: LEgAL Writing AND OdD Notions That PRACTICE TAINTS SCHOLARSHIP}

Consistent with the foregoing, we should call out the odd Langdellian notion that practice experience taints scholarship. ${ }^{62}$ As a part of this, we should also reject the disparate and disparaging treatment of professors with practice experience who teach legal writing or other subjects. ${ }^{63}$ The legality of this form of disparate treatment is beyond the scope of this paper. I leave it to the reader to picture the spectacle of a lawyer arguing to a jury that a legal writing or clinical professor over forty years of age with many years of practice experience is less qualified to teach law and deserves substantially less pay and fewer voting rights than a much younger "doctrinal" professor who has never practiced law. Professors who teach legal writing should help lead this charge both directly and indirectly. Once more, as long as we must use the term "doctrinal," law professors who teach legal writing (and all others) should refuse to say such things as "How does the time required for students' doctrinal course assignments compare with the time required for students' legal writing assignments?"

56 See Benjamin K. Bergen, Louder than Words: The New Science of How the Mind MAKes MEANING 71 (2012).

57 See id.

58 George Lakoff, Foreword to BERGEN, supra note 56, at x.

59 See BERGEN, supra note 56, at 25.

60 See Lloyd, Wordsworth, supra note 28, at 8-13.

61 See generally Coughlin, supra note 22 (on objective legal writing); RocKLIN, supra note 41 (on persuasive legal writing).

62 See Lloyd, Exercising Common Sense, supra note 5, at 1239.

${ }^{63}$ See id. at 1245. 
Instead, they should say such things as: "How does the time required for students' other doctrinal course assignments compare with the time required for students' legal writing assignments?" Better still, we should all drop the problematic "doctrinal" and "non-doctrinal" labels, and judge courses by how "meaningful" they are in the full senses discussed above. ${ }^{64}$ Freed from distortions of such problematic terms, we can better grasp the profoundly meaningful and modern example of legal writing courses today. ${ }^{65}$

${ }^{64}$ See, e.g., Lloyd, Theory Without Practice, supra note 1, at 78; discussion supra Section II.E; supra Section IV.

65 See generally Coughlin ET AL., supra note 22 (on objective legal writing); RocKLIN ET AL., supra note 41 (on persuasive legal writing). 
